\title{
Study of Evapotranspiration in Context of Changing Climate
}

\author{
S .Shekhar \\ Department of Civil Engineering, Indian Institute of Technology, BHU, Varanasi. India
}

\begin{abstract}
It seems imperative to study evapotranspiration (ET) more broadly as a need of hour because in context of climate change as the average temperature is rising; certainly the evaporative demand is shooting up. The present study provides idea about likely change in evapotranspiration due to change in climatic parameters in context of changing climate. As different methods of estimating ET responses differently in specific meteorological parameters on ET demand. The change in temperature causes change in other parameters such as humidity, wind speed, and vapour pressure which ultimately changes ET. In the present study ten years (2002-2011) weather data taken from Ozone unit, Indian Meteorological Department, Banaras Hindu University (BHU), Varanasi, has been analysed for the change in temperature, wind speed and net radiation. It is found that an increase in $14.87 \%$ of total ETo demand with increase in temperature by $20 \%$ for FAO 56 PM model, which is followed by net radiation (13.6\%) and wind speed (4.16\%) in comparison with temperature. While among the other ten temperature and radiation based methods taken up for same study Hargreaves \& Samani temperature based method shows the highest change (21.87\%) to temperature \& solar radiation (Rs) based Irmak model evaluates least change (5.5\%) for $20 \%$ increase in temperature. Moreover, the details of the various combinations of changes in different parameters have been analysed. Further, it is found that approximatelyloc increase in temperature could increase ETo by 30 m.m per year. It means it would require a huge amount of extra water to cater the need of several thousands of hectares of crops per year.
\end{abstract}

Keywords: FAO 56 PM, Evapotranspiration, climatic parameters, temperature, net radiation, wind speed.

\section{Introduction}

In today's world, the water is becoming more \& more scare, not only affecting the per capita water demand, also the water for the agricultural and other purposes are approaching to the stress level. So, it is the utmost important to know each and every controlling factor of water losses qualitatively as well as quantitatively. In this regard, in the water cycle, the least understood and most complicated phenomenon, evapotranspiration (ET) needs to be understood. Also, the factors which controls the ET and how much or till what extent they affect the phenomenon of ET. Therefore, it seems imperative to study ET more broadly as a need of hour because in context of climate change as the average temperature is rising; certainly the evaporative demand is shooting up.

The present study provides idea about likely change in evapotranspiration due to change in climatic parameters in context of changing climate. As different methods of estimating ET responses differently in specific meteorological parameters on ET demand. The change in temperature causes change in other parameters such as humidity, wind speed, and vapour pressure which ultimately changes ET. As, the FAO56 PM method is the standard sole method for the determination of ET, it is used as the main method to compare the results as well as the dependency of meteorological parameters.

\section{Methodology}

The relative sensitivity has been examined to compare the importance of different meteorological parameter. Also, we have climatic data (2002-2011); with all those data the sensitivity of ETo has been checked \& evaluated. This analysis shows the relative importance of climactic parameters that affect the evapotranspiration. As FAO56 PM is currently used and is considered to be a standard method. First, FAO56 PM method is used to evaluate the importance of independent parameters such as temperature, wind speed, net radiation. Again, the different temperature and radiation-based models were taken into consideration towards checking \& evaluating the sensitivity of meteorological parameters for every year.

All these analysis have been arranged in the tabular form. The average of the entire ten years analysis is presented in the form of graph to visualise it clearly.

\section{Study Area \& Data Collection}

This study has been carried out in the Banaras Hindu university campus, Varanasi, Uttar Pradesh, India. The daily average data of last ten years (2002-2011) collected from the Ozone unit, Indian Meteorological Department, Banaras Hindu University Campus, Varanasi. Figure 1 shows the location of study area, situated at $25^{\circ} 18^{\prime} 0^{\prime \prime} \mathrm{N}$ latitude and $83^{\circ} 01^{\prime} 0^{\prime \prime} \mathrm{E}$ longitude at an altitude of $76.0 \mathrm{~m}$ above the mean sea level. The main river 
system in the study area is Ganga River system. The study area comes under humid subtropical region with an average annual rainfall of $1,047.96 \mathrm{~mm}$. The rainfall pattern in the region is very erratic as evidenced from the high amount of rainfall $963.71 \mathrm{~mm}$ during rainy season June to October. While the weekly average data collected from department of agronomy, Institute of Agricultural Sciences, BHU observatory for the period of five years (2007-2011). The mean maximum temperature $32.8^{\circ} \mathrm{C}$, mean minimum temperature $26.3^{\circ} \mathrm{C}$, mean maximum relative humidity $87 \%$, mean minimum relative humidity $64 \%$, average daily actual sunshine duration $7.02 \mathrm{hr}$, average net radiation $13.3 \mathrm{MJ} \mathrm{m}^{-2} \mathrm{day}^{-1}$, and average wind velocity $0.68 \mathrm{~m} \mathrm{~s}^{-1}$.

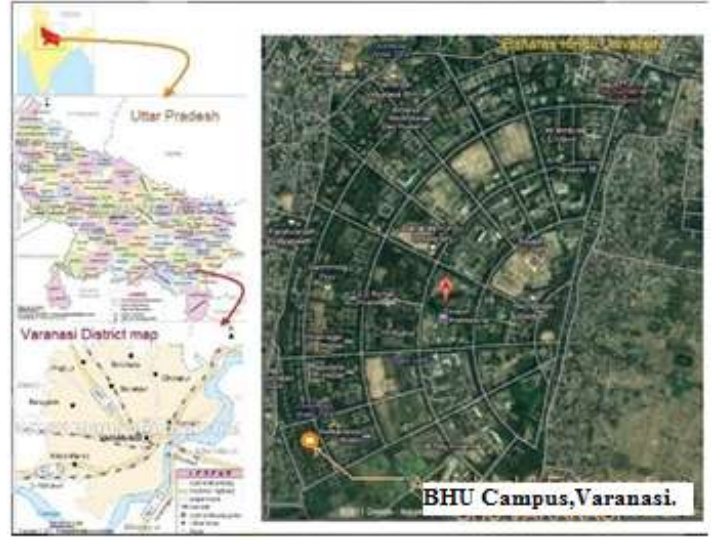

Figure: 1 Location of study area

\section{Results}

Ten years daily average meteorological data has been used to evaluate the interdependency of the climatic parameters to ETo. These data has been shown in the table form (see Appendix A).

The change in different parameters such as temperature, wind speed, net radiation changes different equation in different manners. Sometimes a direct linear relationship can be obtained, but most of the time it varies with certain variation in percentage change. The average of all the ten year (2002-2011) values of percent change has been plotted in the form of graph as below. The figure 2 clearly depicts that due to the change in temperature all the eleven data series shows change in ETo. Series II shows maximum change in ETo due to change in temperature, which is approximately $11.02 \%$ for change in $10 \%$ in temperature while series IV shows minimum sensitivity to temperature which is $2.75 \%$ change in ETo due to $10 \%$ change in temperature.

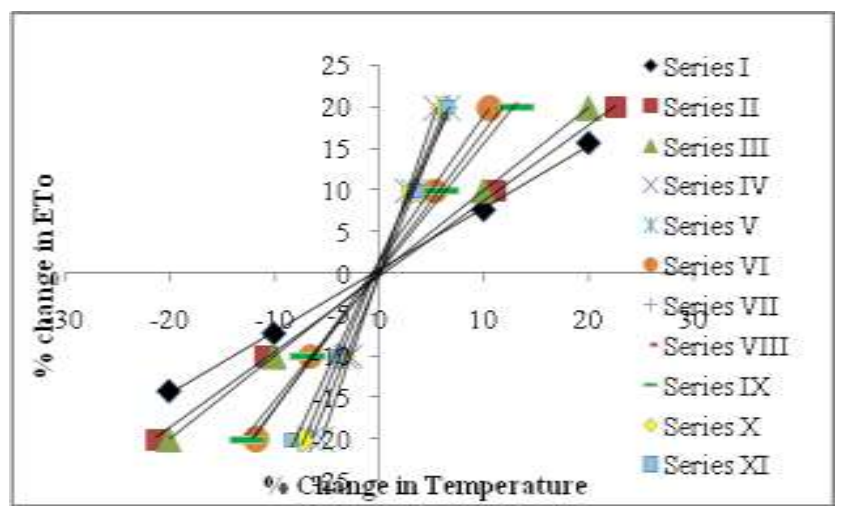

Figure2. Percent change in ETO due to percent change in temperature

Where, I = FAO 56 PM equation, II = Hargreaves \& Samani equation, III $=$ Schendle equation, IV = Solar Radiation based (Rs) Irmak, V = Solar Radiation based (Rn) Irmak, VI = Mass transfer based Romanenko equation, VII = FAO 24 Radiation method, VIII $=$ Hargreaves Radiation method, IX = Priestley - Taylor Radiation method, $\mathrm{X}=$ Makkink model, $\mathrm{XI}=$ Turc method.

The figure 3 clearly depicts that due to the change in wind speed only series I, FAO 56 PM method which shows $2.11 \%$ change in ETo for 10 percent change in wind speed and series VII, FAO 24 Radiation method, which shows only $0.50 \%$ change in ETo for $10 \%$ change in wind speed.

The figure 4 clearly depicts that due to the change in wind speed only series I, FAO56 PM, which shows $6.81 \%$ change in ETo values dur to $10 \%$ change in net radiation and series IX, Makkink model show linear changes in ETo i.e $10 \%$ change in ETo due to $10 \%$ change in net radiation. 


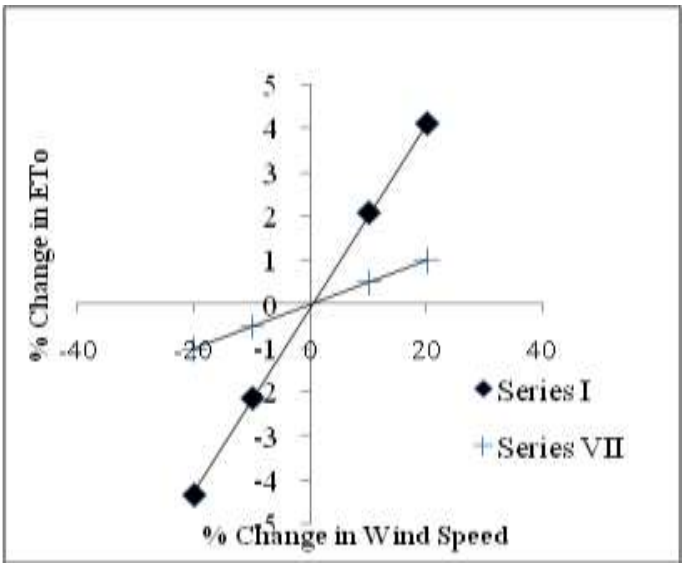

Figure3. Percent change in ETo due to percent change in wind speed

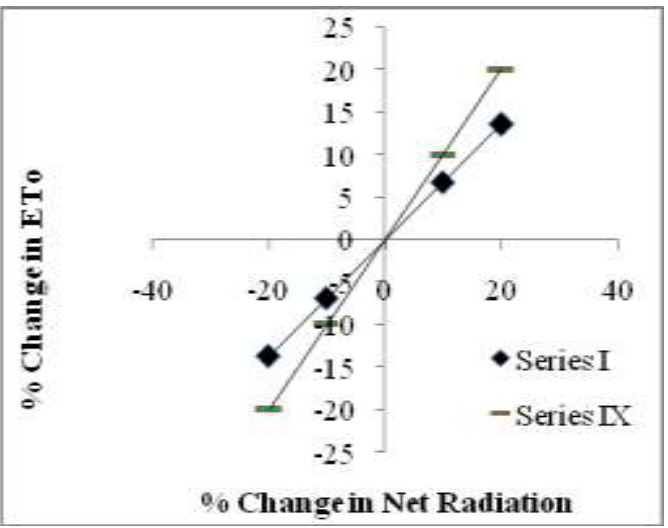

Figure4. Percent change in ETO due to percent change in net radiation

\section{Conclusion \& Suggestions}

The study has revealed a widely varying performance of different equations and, acknowledging that PM and all other methods require local calibration, has reached the following conclusions:

I. On examining the relative sensitivity of ETo to different input variables, it is found that an increase of $14.87 \%$ of total ETo demand with increase in temperature by $20 \%$ for the FAO 56 PM model. ETo is less sensitive $(13.60 \%)$ to increase in net solar radiation, followed by wind speed $(4.16 \%)$ in comparison to temperature.

II. While among other ten models, Hargreaves \& Samani temperature model showed the highest sensitivity $(21.87 \%)$ to temperature, \& solar radiation $\left(\mathrm{R}_{\mathrm{s}}\right)$ based Irmak model evaluates least sensitivity $(5.50 \%)$ for $20 \%$ increase in temperature values.

III. While only FAO 24 radiation model show sensitivity of ETo towards wind speed (4.23\%) and Priestely Taylor radiation method show sensitivity of ETo towards the net radiation $\left(\mathrm{R}_{\mathrm{n}}\right)$ by $20.00 \%$ for $20 \%$ increase in the wind speed and net radiation values.

\section{References}

[1] Allen et al., 1998 Allen, R.G., Pereira, L.S, Dirk Raes, Martin Smith, 1998. Crop evapotranspiration. FAO Irrigation and Drainage Paper 56, Rome, p. 300

[2] Bandyopadhyay A, Bhadra A, Raghuwanshi NS, Singh R. 2009. Temporal trends in estimates of reference evapotranspiration over India. Journal of Hydrologic Engineering 14(5): 508-515.

[3] Bhabagrahi Sahoo, Walling I, Bidyut C. Deka, Bhagwati P. Bhatt, 2011. Standardization of reference evapotranspiration models for a sub humid valley rangeland of eastern Himalayas. Journal of Irrigation \& drainage Engineering, doi: 10.1061/ (ASCE) IR. 19434774.0000476.

[4] Deepak Jhajharia, Yagob Dinpashoh, Ercan Kahya, Vijay P. Singh and Ahmad Fakheri-Fard 2011. Trends in reference evapotranspiration in the humid region of northeast India. Hydrol. Process.Published online in Wiley Online Library (wileyonlinelibrary.com) DOI: 10.1002/hyp.8140.

[5] Dinpashoh Y, Jhajharia D, Fakheri-Fard A, Singh VP, Kahya E. 2011. Trends in reference crop evapotranspiration over Iran. Journal of Hydrology 399: 422-433. DOI:10.1016/j.jhydrol.2011.01.021.DOI:10.1029/2007GL031166.

[6] Goyal RK, 2004. Sensitivity of evapotranspiration to global warming: a case study of arid zone of Rajasthan (India). Agricultural Water Management 69: 1-11.

[7] Hossein Tabri, Mark E. Grismer, Slavisa Trajkovic. 2011. Comparative analysis of 31 reference evapotranspiration methods under humid conditions. Irrigation Science DOI 10.1007/s00271-011-0295-z. 
[8] Irmak, S., Irmak, A., Allen, R.G., and Jones, J. W. 2003. "Solar and net radiation-based equations to estimate reference evapotranspiration in humid climates." Journal of Irrigation and Drainage Engineering. ASCE. 129(5):336-347.

[9] Lakshman Nandagin, Gicy M. Kovoor. 2005. Sensitivity of the food and agriculture organization Penman-Monteith evapotranspiration estimates to alternative procedures for estimation of parameters.238-248/Journal of Irrigation \& Drainage Engineering $\odot$ ASCE /May/June 2005.

[10] Semalty P D 2011. Estimation of forest evapotranspiration over Uttarakhand hills, India Indian J. Phys. Vol. 85, No. 8, pp 1277-1285.

[11] Slavisa Trajkovic. 2007. Hargreaves Verces Penman-Monteith under Humid Conditions. 38-42/Journal of Irrigation \& Drainage Engineering @ASCE/ January/ February 2007.

[12] Thomas A. 2000. Spatial and temporal characteristics of potential evapotranspiration trends over China. International Journal of Climatology 20: 381-396.

[13] Xu CY, Gong LB, Jiang T, Chen DL, Singh VP. 2006. Analysis of spatial distribution and temporal trend of reference evapotranspiration and pan evaporation in Changiiang (Yangtze River) catchment. Journal of Hydrology 327: 81-93.

[14] Zhang X, Ren Y, Yin ZY, Lin Z, Zheng D. 2009. Spatial and temporal variation patterns of reference evapotranspiration across the Qinghai- Tibetan Plateau during 1971-2004. Journal of Geophysical Research, 114: D15105. DOI: 10.1029/2009JD011753. 